KARNAWALIZACJA GROZY W FOLKLORZE DZIECIECYM

$$
\begin{array}{r}
\text { Go to sleep, may you die in your sleep, } \\
\text { That the priest come to take you keep! } \\
\text { Ninna...oh Ninna...oh! } \\
\text { To whom shall I give this little girl? } \\
\text {...to the bogeyman I'll give her. } \\
\text { For a whole day he will keep her... }
\end{array}
$$

ludowa kołysanka (Warner 2000: 162)

\title{
Wprowadzenie
}

Jerzy Cieślikowski, znawca folkloru dla dzieci i folkloru dziecięcego, twierdzi, że strach jest jednym z pierwszych przejawów życia emocjonalnego człowieka, a folklorystyczne utwory z elementami grozy obecne są w życiu dziecka od narodzin, czego znakomitym przykładem mogą być śpiewane niemowlętom kołysanki, których nastrojowość bywa ambiwalentna, niepokojąca, a obrazowanie mroczne, czasami wręcz katastroficzne i przejmująco smutne (Cieślikowski 1985: 111) ${ }^{1}$. Badacz podkreśla, że dzieci od zawsze istniały w ścisłym zespoleniu z grozą - straszone przez dorosłych lub straszące siebie nawzajem podczas zabawy:

Dzieci straszy się na pewno nie tylko z naiwnej i nierozsądnej intencji pedagogicznej - aby były grzeczne. Straszy się je z własnej, głęboko ukrywanej lub ledwie uświadamianej przyjemności sadystycznej. Dzieci straszą też same siebie, robiąc to z dreszczem masochistycznej rozkoszy (tamże).

Cieślikowski, pisząc o straszeniu dzieci przez dorosłych, ma na myśli monsterologię pedagogiki ludowej oraz zbudowaną na niej XIX-wieczną „,czarną pedagogikę" - system wychowawczy, który polegał na straszeniu dzieci figurami demonicznych monstrów, pełniących funkcję „strażników” norm i zasad obowiązujących najmłodszych (Rudolf 2001: 3). Folklor ludowy oraz „czarna pedagogika" generowały zatem obrazy straszydeł używanych przez dorosłych do wymuszania na dzieciach swoistego „gorsetu” zachowań społecznych (Slany 2016a: 65). Marina Warner uważa, że dla dzieci najmłodszych groza sprowadza się do demonicznych straszydeł właśnie, o których istnieniu przekonani jesteśmy w dzieciństwie (Warner 2000: 44). Cieślikowski mówi z kolei o istnieniu grozy

${ }^{1}$ Marina Warner przeprowadza analizę mrocznych kołysanek i twierdzi, że celowo przywołują one nocne lęki, katastroficzne obrazy, sceny makabryczne, sytuacje graniczne oraz transgresyjne, gdyż nie mają na celu uspokajać i koić odbiorcy, ale budzić jego niepokój (Warner 2000: 12). Na temat mrocznej strony kołysanek przeczytać można w pracach Katarzyny Wądolny-Tatar (2014). Kołysanka $w$ liryce XX $i$ XXI wieku. Emergencja gatunku literackiego. Kraków: Wyd. Naukowe Uniwersytetu Pedagogicznego oraz Magdaleny Joncy (2005). Enfants terribles. Dzieci złe, źle wychowane w literaturze polskiej XIX wieku. Wrocław: Wydawnictwo Uniwersytetu Wrocławskiego. 
archetypicznej, która w dzieciństwie wiąże się z lękiem przed nocą, ciemnością $\mathrm{i}$ istotami je personifikującymi, $\mathrm{w}$ różnych kulturach mającymi wiele wcieleń (Cieślikowski 1985: 112). W Polsce dzieci długo bały się dziada z worem, kominiarza, Cygana, diabła, Baby Jagi, Baby Jagodowej, Baby Grochowej, Baby Cmentarnej, Cichej (demon morowego powietrza), jędzy, czarownicy - kumy diabelskiej, Strzygi, Mrucka, bobaka (inne nazwy: bobo, bebok, bobok) - odpowiednika fauna maleńkiego, kosmatego straszydła o starej twarzy wyłażącego z pieca, piwnicy i strychu, ale też spersonifikowanej śmierci oraz monstrów wywiedzionych z podań wierzeniowych - m.in. wampira, upiora, wilkołaka, wisielca, utopca czy zmory (Zych, Vargas 2015: 32-96). Popularny był również Gniotek, zmór nocny, przedstawiany jako „mały, gruby chłopiec, z wielkim brzuchem (...). Dusi on we śnie śpiących, że spać nie mogą, ale najpierw wyjmuje ze swego brzucha kiszki, boby tego, co dusi, zgniótł ciężarem" (Cieślikowski 1985: 113). Polskie dzieci straszono także wiedźmami, mamunami, boginkami, dziwożonami, marudami, nocnicami, południcami, które porywały ludzkie niemowlęta i podrzucały własne brzydkie i poczwarne, ale też torturowały, a nawet bestialsko grzebały dzieci żywcem (Jonca 2005: 148, 165). Postrachami niegrzecznych dzieci byli też Strala „diabeł w wietrze, zasraniec”, którego słychać w pojękiwaniach wiatru, Didko, zwany Dydkiem, Bucem lub kurzym płuckiem i zły dziad, który czaił się w ciemnościach chałup (Cieślikowski 1985: 117-118).

Prześladowcy dzieci w pedagogice ludowej mają różnorodną postać, oprócz wymienionych wyżej wskazać można uniwersalne sylwetki olbrzymów, ogrów, trolli, ożywionych trupów oraz wszelkich innych straszydeł - poczwarnych, obleśnych, parszywych, które według Magdaleny Joncy stanowią „panoptikum zmór - kidnaperów i dzieciożerców" (Jonca 2005: 165)․․ Określenie Joncy bliskie jest terminologii zastosowanej przez Warner w pracy No Go the Bogeyman. Scaring, Lulling and Making Mock, w której w stosunku do wszystkich straszydeł i dzieciożerców, wywiedzionych $\mathrm{z}$ demonologii ludowej różnych kultur, stosuje synonimiczne i uniwersalizujące nazwy: Bogeyman, Bugbears, Boo-baggers (Warner 2000: 31). Badaczka twierdzi, że „wzbudzający strach maruderzy $\mathrm{z}$ kołysanek oraz baśni i gotyckich fantazji, zamieszkuja świat cieni: to coś, co przychodzi nocą, a towarzyszy im lęk przed ciemnością" (tamże, 334) ${ }^{3}$. Najbliższe dzieciom są straszydła (boo-baggers), pożeracze dzieci (child-guzzlers) i „przerażacze dzieci” (child-frighteners), którzy dźwigają torby, do których pakują złapane ofiary (tamże, 27). W literaturze fantastycznej, dzięki opowiadaniu Ernsta T. A. Hoffmanna, rozpoznawalny jest szczególnie Piaskun (Hoffmann 1999: 98-129) - (sandman) - zmór nocny zakradający się do pokoju dziecinnego, który wkłada dzieci do torby i porywa je na księżyc jako jedzenie dla własnych pociech, wcześniej jednak wydłubuje ofiarom oczy (Warner 2000: 31). Zdaniem Warner straszydła i dzieciożercy do dziś stanowią narzędzie służące do wymuszania na dzieciach właściwego zachowania oraz sankcjonowania ustalonego przez opiekunów porządku (tamże, 11). Badaczka omawia wcielenia Bogeymana w demonologiach, mitach, baśniach, kołysankach, w folklorze dla dzieci, w folklorze dziecięcym, a nawet $\mathrm{w}$ kierowanych do różnych adresatów mrocznych tekstach

${ }^{2} \mathrm{~W}$ wierszykach dziecięcych często pojawia się słynna piosenka baśniowych olbrzymów: „Fee-fi-fo-fum!/ I smell the blood of an Englishman/ Be he alive, or be he dead/ I'll grind his bones to make my bread" - odnaleźć ją można w klasycznych zbiorach baśni literackich oraz w angielskim folklorze dziecięcym (Evers 2014: 161).

3 Przekład własny za: „The feared marauders of lullabies and fairy tales and Gothic fantasies inhabit a world of shadows: they are things that come in the night, and they approach with fear of the dark". 
literackich i filmowych. Osobno prezentuje dawne i współczesne zabawy karnawałowe, festyny, parady, procesje, maskarady, przedstawienia teatru kukiełkowego, świeckie rytuały i ceremonie, popularne praktyki magii, czarów i zabobonu, które Bogeymana reprezentują i rytualnie go wyśmiewają lub uśmiercają (tamże, 14).

Należy zwrócić uwagę, że obok rytualnego straszenia dzieci pojawia się kwestia osobna - zafascynowanie dziecka grozą, które objawia się grozotwórczymi wyobrażeniami na podstawie zasłyszanych baśni lub oglądniętych bajek animowanych oraz włączaniem poetyki grozy do zabaw gestycznych, słownych i ruchowych typowych dla najmłodszych. Antoni Kępiński twierdzi, że dzieciom łatwiej niż dorosłym przychodzi uwierzyć w istnienie grozy, gdyż „wyobraźnia dziecka jest żywsza niż człowieka dorosłego (...)", łatwiej im też wkraczać w świat ufundowany na mrocznej baśniowości czy poetyce strachu, mimo że w odbiorze dziecięcym „baśń ta bywa nieraz przerażająca” (Kępiński 1979: 88-89). Uczony dodaje, że „dzieci lubią słuchać strasznych baśni, chłopcy chętnie narażają się na niebezpieczeństwa nie tylko dlatego, by zaimponować rówieśnikom, lecz także, by w sobie zwalczyć uczucie lęku" (tamże, 137). W przypadku dzieci młodszych - zdaniem Kępińskiego - konfrontacja z lękami ma miejsce głównie podczas zabawy, kiedy zauważyć można

zjawisko swoistego igrania z lękiem. Dzieci jakby dla zabawy wystawiają się na sytuacje lękowe, [...], słuchają strasznych baśni, bawią się w duchy, zbójców, wybierają się w nocy na cmentarz. Fascynację tego typu zabawami stanowi zwycięstwo nad własnym lękiem. Z punktu widzenia indywidualnej ewolucji jest to zabawa ze wszech miar pożyteczna, uczy bowiem walki $\mathrm{z}$ własnym lękiem, a przezwyciężanie lęku jest warunkiem ekspansji w świat otaczający (tamże, 158-159).

Śmiało można stwierdzić, że dzieci znaja podstawowy repertuar strachu i potrafią go zarówno demonizować, choćby w sferze wyobrażeń, jak i oswajać podczas zabawy (Slany 2016a: 12). Stefania Wortman zaznacza, że dzieci młodsze uwielbiają inscenizować zabawy, w których pojawiają się straszydła, takie jak śmierć, duch, olbrzym, wiedźma, upiór i inne, zaprezentowane zawsze w formie gargantuicznej, budującej napięcie, które pod koniec zabawy zostają zneutralizowane poprzez przedrzeźnienie $\mathrm{i}$ ośmieszenie oraz wykpienie makabrycznej scenerii czy poważnego nastroju (Wortman 1958: 176). Badaczka, która często opowiadała dzieciom baśnie podczas spotkań bibliotecznych, mówiła, że najbardziej lubiły one repertuar frenetyczny, makabryczny oraz finałowe okrutne zemsty na oprawcach (tamże, 177). Zdaniem Wortman „większość dzieci (...) słucha [strasznych opowieści - K.S.] z rozkoszą, zaliczając (...) przestrach do uczuć, które mogą dostarczyć wielu silnych, lecz bynajmniej nie przykrych wrażeń" (tamże, 178). Wspomina, że dzieci z fascynacją słuchały opowieści grozy i były bardzo rozczarowane, gdy celowo pomijała sceny okrucieństwa, makabry, zbrodni (tamże, 179). Przerywały wówczas opowiadanie i prosiły o uzupełnienia lub same dodawały pominięte fragmenty (tamże, 180). Warto nadmienić, że Wortman była zwolenniczką usuwania grozy z opowieści kierowanych do dzieci, postrzegała ją bowiem jako szkodliwą dla psychiki dziecięcej, dlatego w książce Baśń w literaturze $i$ w życiu dziecka. Co $i$ jak opowiadać? pisała: „mamy prawo usunać rozżarzone pantofelki, w których musi tańczyć aż do śmierci zła macocha królewny Śnieżki, opuszczać beczki nabijane gwoździami, włóczenie końmi i tym podobne tortury" (tamże, 177). Tymczasem dzieci - co dobitnie podkreśla Bruno Bettelheim w dziele Cudowne i pożyteczne. O znaczeniach $i$ wartościach baśni - im bardziej „odziera” się przeznaczone dla nich utwory z topiki makabry, okrucieństwa i grozy, tym bardziej się jej domagają lub bronią jej zawzięcie (Bettelheim 2010: 55). 
Dzieci są zafascynowane właśnie scenami tortur, strasznymi karami na oprawcach, estetyką obrzydliwości, które wzbudzają w nich strach, ale jednocześnie pozwalają im odczuć ulgę, kiedy w finale zbrodniczy bohater zostaje w okrutny sposób zamordowany. Znakomitym przykładem jest opis Warner, która wspomina zachowanie dzieci w teatrze podczas spektaklu o Jasiu i Małgosi:

Pamiętam, jak widownia teatru zapełniła się piskiem i krzykiem sześciolatków ogarniętych zachwytem i przerażeniem, gdy Małgosia wepchnęła czarownicę do pieca, a ta nadal wyrywała się i rzucała ku dziewczynce, aby ją złapać i pochwycić swymi długimi szponami i żółtymi kłami. W końcu, gdy Małgosi udało się zatrzasnąć za nią drzwiczki od pieca, czarownica nadal wydobywała się spod desek podłogi, wymachując jedną, szponiastą ręką jak w filmie grozy widownia wpadła wówczas w ten specyficzny stan histerycznej radości pomieszanej ze strachem, która daje $\mathrm{w}$ efekcie śmiech określany jako szczególnie dziecinny, a który same dzieci nieustannie w sobie wywołują i rozniecają (Warner 2000: 17-18) . $^{4}$.

Ponadto, nie tylko o poczucie sprawiedliwości dzieciom chodzi, Joanna Papuzińska zauważa bowiem, że sceny makabryczne, obrzydliwe, upiorne, skatologiczne, straszne są według najmłodszych po prostu bardzo śmieszne i pozwalają im na konfrontację $\mathrm{z}$ wyobraźniowymi lękami:

[...] zmierzenie się z własnym strachem pełni dla dzieci funkcję ludyczną, jest formą zabawy, że rzeczy makabrycznych nie biora one na serio, ale raczej traktują jako żart, element symbolicznego „świata na opak” i że na przykład „,człowiek, któremu odpadła głowa i który jej szuka, wydaje im się bardzo śmieszny" [...]. Dzieci właśnie dlatego uwielbiają grę ze strachem, że nie mają poczucia zagrożenia, a rzeczy przerażające wydają im się absurdalne (Papuzińska 1996: 81).

Przywołani znawcy folkloru dla dzieci i folkloru dziecięcego twierdzą, że właściwego stosunku dzieci do grozy poszukiwać trzeba bezpośrednio w ich twórczości, czyli w folklorze dziecięcym. Artykuł ten poświęcony jest zatem nie grozie w literaturze dziecięcej, lecz specyficznemu obliczu grozy, które odnaleźć można w rymowankach improwizowanych podczas zabawy przez dzieci w wieku przedszkolnym, oraz w krótkich opowiastkach strachu (ghoulish stories) wymyślanych przez dzieci w młodszym wieku szkolnym (Goldstein, Grider, Banks 2007: 111). Według Warner wierszowane makabreski i straszne historyjki posługują się śmiechem rewolucyjnym, obrazoburczym, buntowniczym i patronuje im funkcja ludyczna (Warner 2000: 328). Dzieci uwielbiają wymyślać okropne wierszyki i opowiastki, czerpią też satysfakcję $\mathrm{z}$ ich wspólnego opowiadania, słuchania i przekładania na sytuację zabawy. Repertuar ten żyje w ludycznym świecie zabaw dziecięcych, przechowywany i modyfikowany przez kolejne generacje, jednak, co trzeba podkreślić, rdzeń tych utworów pozostaje niezmienny (Goldstein i in. 2007: 138).

Dzieci młodsze mają ogólną wiedzę na temat nastrojowości tekstów grozy czy charakterystycznych dla nich motywów i tematów, ale znakomicie orientują się w kwestii przypisanych grozie straszydeł. We własnych utworach odwracają standardowy sposób postrzegania ich jako źródeł lęku i egzorcyzmują je humorem,

${ }^{4}$ Przekład własny za: „I have heard a theatre full of six-year-olds shriek with delighted terror when Gretel pushed the witch into the oven and she kept coming back to grab the little girl with her long nails and yellow fangs. Eventually, even after Gretel had manager to slam the oven door on her, the witch still emerged from under the floorboards, waving one clawed hand as in a horror film - to the ethat special state of heebie-jeebies, the response of mixed joy and terror that produces laughter have been identified as peculiarly childish and are constantly being provoke and reinforced in children themselves". 
przedrzeźniając i ośmieszając (według Warner kluczowymi terminami są tu: mocking, ridiculing, clowning) (Warner 2000: 117). Dzieci cieszy przede wszystkim ośmieszanie atrybutów i zachowań przypisanych monstrom, bestiom, potworom i straszydłom, które poprzez rytualne ośmieszenie zostają „odarte” $\mathrm{z}$ wpisanej w ich naturę krwiożerczości (mocking their original natures) (tamże, 18). Strachy spod łóżka czy te ukryte w szafie pozostają pod kontrolą dziecka ${ }^{5}$, które ma świadomość dokonywania pewnego rytuału odczyniania grozy poprzez zaprezentowanie jej z perspektywy ludycznej, absurdalnej, groteskowej, czego konsekwencją jest przekształcenie pierwotnych niepokojów w przyjemność. „Metamorficzny humor, który potrafi zawładnąć stworami wywołującymi strach i zamienić je w coś innego, coś uspakajającego, a nawet pożądanego, stanowił od zawsze szeroko przyjęty i powszechnie stosowany fortel w konfrontacji ze strachem" (tamże, 19) ${ }^{6}$.

Rymowanki i opowiastki strachu to utwory bardzo proste w swej formie i poetyce, najbliższe estetyce karnawału, stąd liczne hiperbole, degradacje, profanacje, absurdy językowe, obscena, wątki skatologiczne, wulgaryzmy, powtarzalność mocnych (refrenowych) fraz oraz ludyczna puenta. Dominująca reguła karnawału polegająca na hiperbolizacji fantomów strachu i ich groteskowej decentralizacji, zwieńczona jest głośnym, chóralnym śmiechem dzieci, jaki towarzyszy sytuacji, gdy mały przechytrza silnego (Slany 2016a: 135). Repertuar ten powstaje na przekór dorosłym, dzieci mają bowiem satysfakcję $\mathrm{z}$ łamania tematów tabu i wprowadzania w konsternację starszych od siebie, którzy uważają, że nie powinny one interesować się grozą ze względu na domniemaną niewinną naturę i wrażliwą psychikę. Nie dostrzegają, że w utworach dziecięcych sfera zaświatów, niesamowitości i symboli strachu zostaje silnie uplastyczniona, skarnawalizowana - oswojona. Karnawałowe oblicze grozy jest zaś manifestacją „radości, aktywności, pełni i substancjalności prawdziwego życia” (Sznajderman 1994: 20).

\section{Karnawalizacja grozy w folklorze dziecięcym}

Folklor dziecięcy rozumiany jest tutaj za Cieślikowskim jako słowna aktywność dziecka towarzysząca zabawie,

w której akt twórczy jest świadomy; pojawia się spontanicznie lub jako wynik przemyślenia wyboru i naginania środków wypowiedzi do określonej koncepcji. [...] najczęściej mamy do czynienia z kreacyjnością, która dokonuje się równolegle z pojawieniem się tematu czy idei. Tworzenie ma charakter krótkich improwizacji, zarówno semantycznych, jak i czysto dźwiękowych, cieszących urodą brzmieniową. I tu, jak we wszystkich innych wypadkach, jest zabawą; dziecko bowiem bawi się nie tylko kamykami, klockami, ale i myślami (Cieślikowski 1985: 235).

Cieślikowski zauważa, że rymowanki dziecięce, niezależnie od przemian historycznych i społecznych, zachowują tę samą strukturę formalną i językową, dlatego stanowią „żywy materiał twórczy funkcjonalnie i językowo” (tamże, 187). Szczególnie

${ }^{5}$ Ksenia Olkusz twierdzi że „lęk dziecięcy to motyw stwarzający niemałe możliwości interpretacyjne. Może zostać wyjaśniony w kategoriach nadnaturalnych, lecz może zyskiwać także racjonalny wykładnik, tłumacząc się jako niejasny dla dziecka element rzeczywistości. Strach przed ciemnością i „potworem spod łóżka” (lub szafy) są integralnym składnikiem wyobraźni dziecięcej i lęków wczesnego wieku” (Olkusz 2010: 153).

${ }^{6}$ Przekład własny za: „Metamorphic humour, which seizes the objects of fear, like beasts, and turns them into something different, something reassuring and even desirable, has been the most widely and successfully adopted stratagem in the confrontation of fear". 
ważne są wyliczanki, których genezy poszukują badacze w druidzkich sposobach losowania ofiar lub późniejszym dziesiątkowaniu żołnierzy (Pisarkowa 2013: 45), co w kontekście zabaw dzieci w następujący sposób konkluduje Cieślikowski: „I w tym wypadku skazujący wyrok w obdzieleniu kogoś rolą „nieprzyjemną” byłby w zabawie uzasadniony” (Cieślikowski 1985: 187) . Zabawa bowiem - pisze dalej uczony „stanowi swoistą nadbudowę w stosunku do życia „normalnego”; akt bawienia się jest świadomym wyjściem z życia oficjalnego, na serio, w prowizoryczną sferę aktywności, jest formą „czystą", uwolnioną od norm krytycznych postępowania realistycznego" (tamże).

Według Doroty Simonides mikroformy wierszowane, obecne w obiegu ustnym dzieci, pokazują wyraźnie, jakie tematy są najważniejsze dla dzieci w wieku przedszkolnym i młodszym wieku szkolnym (Simonides 1986: 7). Badaczka twierdzi, że wierszyki te odzwierciedlają prawdziwe fascynacje dzieci, którym nadają one specyficzną formę (tamże). Zdaniem Cieślikowskiego już trzyletnie dziecko jest świadome zabawności językowych wywracanek, zaś dziecko w starszym wieku przedszkolnym ma naturalną zdolność i skłonność do tworzenia wierszy o charakterze rewolucyjnym, degradujących porządek świata i prezentujących go jako ,świat na opak" (Cieślikowski 1985: 236). Uczony dowodzi, że utwory dziecięce sa przykładem wyrafinowanego poczucia humoru, typowego dla dzieci młodszych, które symplifikują tematy trudne, straszne, makabryczne, smutne i „odczyniają je humorem” (tamże, 320).

Prostym przykładem jest, omawiana przez Kępińskiego, hierarchiczna relacja między dzieckiem a dorosłym, w której dziecko „dosłownie i symbolicznie patrzy w górę" (Kępiński 1979: 218). Władza rodzicielska wydaje mu się monstrualna, ,jest wyrazem tajemniczego świata społecznego, jest w niej wszechmoc, niepoznawalność i nieodwołalność" (tamże). Dlatego w zabawie i towarzyszących jej improwizowanych wierszach dzieci odwracają społeczną hierarchię, sięgają po władzę absolutną i redukują monstrualność dorosłych do miniatury. Stosuja zabieg infantylizowania i profanowania arbitralnie narzuconych im autorytetów. Znakomitym przykładem jest tutaj rymowanka o Panu Pierdołce:

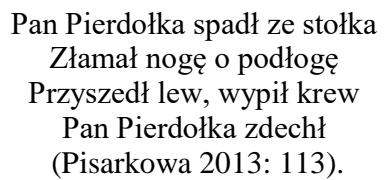

Bohater nosi obscenicznie przezwisko (zgodnie z charakterystycznymi dla folkloru dziecięcego wyzwiskami i przezwiskami), przydarza mu się kompromitująca przygoda, finał zaś typowy jest dla makabresek dziecięcych, w których poniżeni dorośli giną w drastycznych okolicznościach. Zjawiska te egzemplifikują kolejne trzy makabreski, którym patronuje estetyka turpizmu i obrzydliwości:

Czy kotlecik to mielony,

Czy pomidor to czerwony?

Nie, to tatko nasz kochany

Przez tramwaik przejechany.

Raz, dwa, trzy

Wychodzisz ty

(Simonides 1986: 73).

Mój dziadek nieboszczyk

Na glacę się ostrzygł 
I był z tego dumny, Gdy wchodził do trumny (tamże, 99).

\author{
Po wodzie pływa \\ Babcia nieżywa. \\ I robaczki też pływają, \\ Babci pięty podgryzają. \\ Ropka z nosa babci leci, \\ Śmierdzi, cuchnie, moje dzieci \\ (Nowe Fikotki Pana Pierdziołki 2013: 40).
}

Bohaterami są tatko, dziadek i babcia. W rymowance „Czy kotlecik to mielony..." głowa rodziny - ojciec - porównany zostaje do zmielonego mięsa, rozmemłanego pomidora, finał zaś eksponuje jego zmasakrowane ciało przejechane przez tramwaj. Dzieci kpią też ostentacyjnie ze śmierci i profanują uznane przez dorosłych świętości. Żartobliwą reakcją na śmierć jest wizja dziadka - ożywionego trupa - który z kompromitującą go łysą „,glacą” odwraca reguły rytuału pogrzebowego i z typowym dla clowna zadowoleniem wchodzi do trumny. W ostatniej z makabresek pojawia się babcia-topielica, której ciało potraktowane zostaje groteskowo jako strawa dla robaczków i rybek podgryzających zwłoki. Estetykę obrzydliwości i szpetotę pogryzionego truchła podkreśla dwuwersowa puenta: „Ropka z nosa babci leci/ Śmierdzi, cuchnie, moje dzieci” (tamże). We wszystkich makabreskach pojawiają się złośliwe zdrobnienia (Pierdołka, „tatko nasz kochany przez tramwaik przejechany”, „ropka z nosa”), które służą obrazowaniu opartemu na rozkładzie, porównaniu ciała do surowego mięsa, wyolbrzymieniu smrodu zwłok, zaprezentowaniu nie śmierci a zdychania, błazeństwu maszkar i trupów, czyli typowej dla groteski makabry ludyzmem podszytej.

Słowna, gestyczna i ruchowa zabawa dzieci ukierunkowana jest na rozładowanie napięć, niepokojów i lęków poprzez śmiech, który według Michaiła Bachtina ma naturę ambiwalentną, gdyż „wyśmiewa, neguje i zarazem radośnie akceptuje, oswaja świat” (Bachtin 1975: 45). Kultura śmiechu i karnawału, którą omawia Bachtin w dziele Twórczość Franciszka Rabelais'go a kultura ludowa średniowiecza i renesansu, daje się przenieść na grunt kultury dziecięcej, jako że śmiech w naturalny sposób przeciwstawia się systemom oficjalnym, a jego celem jest przypominanie o sztuczności wszelkich hierarchii społecznych i stabilnych wizji świata (tamże). Bachtin czyni śmiech dominantą struktury karnawału, którego „ideologia wyraża się przez sytuacje realne, których (człowiek - K.S.) jest współtwórcą i uczestnikiem” (tamże, 15). Cechy poetyki karnawału według Bachtina to ahierarchiczność, familiarność, parodiowanie usankcjonowanych społecznie wartości, profanacje, mezalianse, ambiwalencje znaczeń, nastawienie na moment zmiany, sytuacje kryzysowe i graniczne, które składają się na uniwersalny i ponadczasowy ,język karnawałowych gestów i symboli” (tamże). Język karnawału staje się więc medium specyficznego widzenia świata i polega na uwalnianiu „świadomości spod władzy oficjalnego światopoglądu” (tamże, 387).

Maria Nikolajeva, dokonując transpozycji Bachtinowskiej teorii śmiechu i karnawału na grunt kultury oraz literatury dziecięcej, zauważa, że językowe i ruchowe zabawy dzieci młodszych mieszczą się właśnie w porządku karnawału, który oferuje im możliwość ludycznego dekonstruowania świata poprzez odwrócenie zasad, norm i wartości (Nikolajeva 2000: 7). Badaczka pisze, że chwilowe odejście od ładu i harmonii $w$ stronę chaosu i degradacji w zabawie dzieci objawia się poprzez zamanifestowanie typowego dla struktury karnawału, zasadniczego gestu, jakim jest 
wzniesienie na piedestał najsłabszego lub najmniejszego w hierarchii społecznej (w średniowiecznym karnawale błazna/głupca) w zabawie - dziecka, które staje się ważne jak król lub dorosły, dzięki czemu może dokonywać spektakularnych zmian i w drastyczny sposób pokazywać władzę (tamże, 8). Nikolajeva zaznacza, że karnawał jest zjawiskiem przejściowym w życiu człowieka - podobnie jak dzieciństwo - dlatego dziecko w roli karnawałowego władcy może tylko na chwilę kreować groteskową wizję świata (tamże, 137). Na mocy myślenia magicznego o świecie, posługując się wyobraźnią, odtwarza ono obronne formuły znane ludzkości od początku jej istnienia które w zabawie czynią je silnym i służą do neutralizowania lęków, obalania niechcianych reguł, przedrzeźniania tego, co straszne, wrogie i narzucone arbitralnie społeczności dziecięcej. Nikolajeva powołuje się bezpośrednio na teorię Bachtina, który za centralny motyw karnawału uznaje błazeńskie koronacje i detronizacje - ideowe sedno „świata na opak” (Bachtin 1975: 297).

Dziecko w roli władcy pozwala sobie nadać archetypicznym postaciom grozy „gębę" - rozumianą po Bachtinowsku - jako maska głupca. W takim systemie obrazowym strach ma twarz błazeńską, a dzieci działają na wzór Bachtinowskiego ludu zgromadzonego na placu, który wybierał błazna, a następnie „lżył go, bił, tak jak jeszcze gdzieniegdzie dziś ośmiesza się, bije, rozrywa na części, pali lub topi zapustowa kukłę zimy czy starego roku” (tamże). W karnawale „wszystko dzieje się na odwrót niż w górnym świecie. Wielcy są detronizowani, mali - interioryzowani” (tamże, 519). Dlatego każda postać grozy zaprezentowana jest w duchu „folklorystycznego głupka, robiącego wszystko na odwrót, wbrew wszystkim normom" (tamże, 571). Nadawanie „gęby clowna” straszydłom oraz przypisanie im cech infantylnych (obfitość rytualnych „upupień”) prezentują następujące rymowanki: „Bum-cy-ry-ku/ Bum-cy-ry-ku/ Siedzi diabeł na nocniku!” (Simonides 1986: 42), „Gonił diabeł diablicę/ Oberwał jej spódnicę/ Wybił zęby trzy/ Teraz wychodź ty!" (Usenko, Wawiłow 2011: 32), „Na śmietniku wielkie krzyki/ Tam się biją nieboszczyki” (Simonides 1986: 100) lub „Zuzia kocha Drakulaka/ A Drakulak jest pokraka/ A Drakulak szczerzy kły/ raz, dwa, trzy/ Wychodź ty!” (Usenko, Wawiłow 2011; 33). W „upupiających” straszydła wyliczankach widać także ostentacyjne wyzwiska i wulgarne odzywki: „Baba jędza, czarownica/ Sekutnica i złośnica/ Wąż gadzina, żmija wściekła/ Stara małpa rodem z piekła/ A tą małpą jesteś ty!” (Simonides 1986: 66). Popularne jest też wyśmiewanie głupoty i zachowań absurdalnych istot demonicznych: „Wyszła świnia na drabinę/ Upuściła apluzynę/ Diabeł myślał, że to dusza/ Wsadził ją do kapelusza" (Nowe fikołki Pana Pierdziołki 2013: 43) lub „Strzyga strzyże uchem/ A jak się nie strzyże/ To się liże" (Simonides 1986: 226). Dzieci prezentują także wywrotki wynikające z podważania koordynacji ruchowej strachów: „Miała baba Lucypera/ Dała mu się najeść sera/ A Lucyper po tym serze/ Zrobił wyścig na rowerze/ A że jechał tak fatalnie/ To się rozbił o latarnię/ A latarnia się wygięła/ Lucypera w łeb trzasnęła" (tamże, 98) oraz degradacje straszydeł zgodne z zasadą „mały przechytrza silnego”: „Leci zombie nocniklotem/ A ja w niego kulomiotem/ Ręka noga mózg na ścianie/ Będzie zombie na śniadanie” (Nowe fikołki Pana Pierdziolki 2013: 45), „Fiku-miku na patyku/ Siedzi wampir na nocniku/ Daj mu kość albo dwie/ Bo jak nie, to cię zje!" (Patka, zapatka, dwa kije 2014: 38).

Groza w wierszach dzieci ma również charakter rubasznie fizjologiczny. Najmłodsi ostentacyjnie sprowadzają na straszydła straszne klęski i groteskowo deformują je do „mięsa”: „Poszła baba po popiół/ Diabeł babę utopił/ Ni popiołu, ni baby/ Tylko z baby dwa schaby" (Nowe fikotki Pana Pierdziotki 2013: 44). Szydercze metamorfozy ciała, związane z gwałtowną i nieestetyczną śmiercią, podkreślane są też 
przez wyzwiska: „Dziadek Zorra jest kucharzem/ Bije wszystkich kałamarzem/ Ludzie myślą, że to zupa/ A on kładzie gęsto trupa/ Raz, dwa, trzy/ Trupem będziesz ty" (Simonides 1986: 76). Dzieci korzystają także z anonimowego zbioru przesądów i wierzeń, uludyczniając je. Przykładowo klecenie masła przez czarownicę nawiązuje do rytuałów magicznych, konkretnie do rzucania uroków (Zych, Vargas 2015: 10). Tymczasem w wizji dziecięcej czynność ta sprowadzona zostaje do rangi banalnego psikusa, który w finale tradycyjnie wiąże się z groteskową sytuacją ,dostawania po łbie”: „Deszcz pada, światło świeci/ Baba-jaga masło kleci/ Nakręciła pół funcika/ Postawiła do kącika/ Przyszedł mąż, masło wziął/ Micha ściep, dostał w łeb" (Simonides 1986: 70) ${ }^{7}$. Dzieci doprowadzają też do konfrontacji dwóch postaci grozy i przewrotnego ich unicestwienia poprzez degradujące uderzenie w brzuch: „Siedzi baba na cmentarzu/ Trzyma nogi w kałamarzu/ Przyszedł duch/ Babe w brzuch/ Baba fik/ A duch znikł” (tamże, 117). Bachtin pisze, że „sam ów tradycyjny gest uderzenia głową w brzuch (lub w zad) jest zasadniczo topograficzny: kieruje nim ta sama logika odwrotności, styczności „dołu” z „górą” (...)” (Bachtin 1975: 428) . W obu wierszach występuje farsowy gest detronizujący: mąż „dostał w łeb”, duch uderzył „babę w brzuch” - te maleńkie sceny są kwintesencją groteski. Podobna farsowa sytuacja ma miejsce w wierszyku: „Był ciemny las/ A w tym ciemnym lesie/ Bardzo czorno chałupa/ A w tej czornej chałupie/ Bardzo czorno trumna/ A w tej czornej trumnie/ Leżoł czorny duch/ Raz, dwa trzy/ Łaps cię za brzuch!" (Simonides 1986: 70). Widzimy tu budowanie nastroju grozy za pomocą uniwersalnych atrybutów strachu czarny las, czarna trumna, czarny duch - połączone z dobrze znaną dzieciom zabawą w „,czarną łapę”. W trakcie zabawy „czarna łapa” jest bardzo aktywna, co wymusza na dzieciach ucieczkę przed nią. W rymowance pojawia się groźba złapania przez ducha, dlatego ważne są wyliczenia będące ostrzeżeniem dla uczestników zabawy, aby nie dali się nikomu złapać za brzuch. Oznaczałoby to bowiem zwycięstwo straszydła i narażenie się na dotyk napiętnowanego - symboliczne naznaczenie „czarną łapą”. W zabawie dziecięcej werbalne i gestyczne przedstawianie straszydeł pełni funkcję perforacyjną: słowa i gesty sprawiają, że rzeczy stają się realne, że rzeczy dzieją się (Warner 2000: 17).

Oprócz zaprezentowanych wyżej postaci grozy w dziecięcych rymowankach wykpione są też inne i co warto podkreślić dzieci nie dokonują żadnej ich systematyki nawet w oparciu o podstawowe kryterium: autentyczne/fikcjonalne. I tak obok diabła, nieboszczyka, Baby Jagi, Lucypera, wampira, strzygi, zombie, Drakulaka, ducha, Gargamela pojawia się Hitler. Zostają oni silnie zinfantylizowani, ukazani w sytuacjach obscenicznych i mocno poniżających. Wynika to $\mathrm{z}$ faktu, że dzieci lubują się w degradowaniu tego, co wysokie i straszne poprzez nadanie temu groteskowej cielesności. W zabawie dziecięcej przewodnim motywem stają się ,groteskowe poniżenia" (Bachtin 1975: 238) oraz prezentowanie nieoficjalnych aspektów grozy, co rozumiem jako dostrzeganie przez dzieci jej podwójnej natury: powagi i monolityczności oraz śmieszności i groteskowości. Warte przywołania są tu wierszyki o Hitlerze, z których najłagodniejszy prezentuje nazistowskiego dyktatora o północy w pociągu pełnym wariatów: „O dwunastej z minutami/ Jedzie pociąg z wariatami/ A w ostatnim wagoniku/ Siedział Hitler na nocniku/ Raz, dwa, trzy/ Wychodzisz Ty!" (Simonides 1986: 105). Złowrogi antybohater zostaje skompromitowany - osadzony

7 Uwspółcześniona wersja tej rymowanki brzmi: „Księżyc jasno świeci/ Baba-Jaga szybko leci/ Wsadza dzieci w worki/ Robi z nich potworki/ Raz, dwa, trzy/ Tym potworkiem będziesz ty!" (Pałka, zapałka, dwa kije 2014: 58). 
w ostatnim wagonie jako osobnik aspołeczny - ukazany w sytuacji załatwiania potrzeby fizjologicznej na dziecinnym nocniku. Ta łagodna degradacja wygląda o wiele rubaszniej w kolejnej obscenicznej rymowance, w której widzimy groteskową wywrotkę, wulgaryzm i dosadną puentę: „Szumi dookoła las/ Hitler na motor wlazł/ Pędzi jak szalony, zgubił kalesony/ Pierdnął i motor zgasł”"8.

W celu wzmocnienia przedrzeźniania strachu dzieci aranżują bitki żywych trupów, zmuszają straszydła do wypinania zadu, siedzenia na nocniku, opluwania się, obrzucania cebulami, uwypuklania groteskowych części ciała (brzucha, zadu, gęby) jak w rymowance, w której diabeł kręci zadkiem przed świętymi: „Siedzi diabeł na stodole/ A słoma go w zadek kole/ I popatrzcie wszyscy święci/ Jak ten dioboł zadkiem kręci" (tamże, 120). Ciekawym przykładem jest też dziecięcy śmiech $\mathrm{z}$ otwartych ust straszydeł, których zatkanie jest sposobem na okiełznanie lęku przed byciem pożartym. Taka sytuacja ma miejsce w innym wierszu o diable, którego „gęba” zostaje błazeńsko wypoczwarzona: „Szły diabły przez piekło/ O holender, jakie ciepło/ Wszystkie diabły pozdychały/ A pozostał jeden mały/ A ten mały co pozostał, to cebulą w gębę dostał" (tamże). Bachtin powiedziałby, że pojawia się tu zasada sprowadzenia strachu do „dołu materialno-cielesnego” (Bachtin 1975: 47). „Dół materialno-cielesny” dla badacza oznacza wprowadzenie do karnawałowej zabawy - oprócz rytuałów degradacji, profanacji, apoteozy błaznów i głupców - obrazów skatologicznych, które symbolizują „,poniżenie topograficzne” (tamże, 234). Skatologiczna logika obrazowa karnawału przykładowo popularne oblewanie moczem, wypróżnienia, porównanie brzucha do mogiły czy zadu do gęby (tamże, 47) - służą uczestnikom zabawy (tutaj dzieciom) odreagowaniu obsesyjnego zainteresowania fizjologią. Za przykład niech posłużą dwie rymowanki, w których wulgarne słownictwo współgra z rubasznymi sytuacjami skatologicznymi. W pierwszej Gargamel skonfrontowany zostaje ze smerfem Lalusiem. Lalusiowi udaje się przechytrzyć czarownika, którego spotyka obsceniczna przygoda: „Jedzie laluś na rowerze/ A Gargamel na Klakierze/ Laluś wjechał w ciemny las/ A Gargamel w gówno wlazł" (Janus-Sitarz 1997: 96). Druga bazuje na znanej z gotycyzmu scenerii cmentarnej i grasujących nocą duchach, z których jeden (,mały duszek") dopuszcza się profanacji grobu ducha od siebie znacznie starszego:

$$
\begin{aligned}
& \text { O dwunastej z minutami wszystkie duchy poszły spać } \\
& \text { Tylko jeden mały duszek wziął papierek, poszedł srać } \\
& \text { Wtem mogiła się otwiera i wychodzi łysy trup } \\
& \text { Na małego się wydziera, czemuś nasrał na mój grób } \\
& \text { Mam cię w dupie, łysy trupie... (Simonides 1986: 60). }
\end{aligned}
$$

Dzieci próbują $\mathrm{w}$ ten sposób ośmieszyć hierarchię narzucaną im przez dorosłych. Finał jest jednoznaczny - mały nie tylko profanuje grób dorosłego ducha, ale bojkotuje go w sferze języka: „mam cię w dupie łysy trupie...” śpiewa. Kurtuazja językowa zastąpiona zostaje przekleństwami i obelgami. Dzieje się tak bowiem, podczas karnawałowej zabawy, dzieci stają się grupą wtajemniczonych w rytuał egzorcyzmowania strachu i celowo nie stosują grzeczności słownej, przemilczeń i eufemizmów, gdyż „użycie takich słów i wyrażeń stwarza atmosferę jarmarcznej szczerości, naprowadza na określoną tematykę i na nieoficjalność samego punktu widzenia rzeczywistości” (Bachtin 1975: 284). Sprowadzanie grozy do „dołu cielesnego" oraz zastosowanie bardzo wulgarnych puent Bachtin wyjaśnia następująco:

\footnotetext{
${ }^{8}$ http://forum.gazeta.pl/forum/f,384,Forum_Humorum.html [dostęp: styczeń 2017].
} 
W sferze twórczości obrazowej kosmiczny strach (jak i każdy strach) był zwyciężany śmiechem. Dlatego kał i mocz, będące śmieszną i cieleśnie zrozumiałą materią, odgrywają tu aż tak wielką rolę. Dlatego występują one $\mathrm{w}$ hiperbolicznych ilościach $\mathrm{i}$ w kosmicznych rozmiarach. Kosmiczna katastrofa, przedstawiana przy pomocy obrazów dołu materialno-cielesnego, zostaje zdegradowana, uczłowieczona i przekształca się w śmieszne straszydło (tamże, 461).

Obrazy skatologiczne są głównym powodem, dla którego większość dorosłych nie zna tych rymowanek. Dzieci dobrze wiedzą, że jest to repertuar tajemny, który powinno się przekazywać tylko innym dzieciom. Przez dorosłych uważany jest za bulwersujący i kontrowersyjny. Warto dodać, że dzieci rezygnują z wyśpiewywania skatologicznych rymów koło dwunastego roku życia, kiedy zaczynają postrzegać je z perspektywy dorosłych i wstydzą się bliskiego im wcześniej „cielesnego” repertuaru (Goldstein i in. 2007: 135).

W omówionych rymowankach zdetronizowane straszydła stają się nosicielami nieoficjalnego porządku i światopoglądu, reprezentantami Bachtinowskiego „dołu materialno-cielesnego". Nabijanie się (making mock) pokazuje rolę, jaką odgrywa żart w łagodzeniu strachu wywoływanego przez straszydła. Ich komiczna metamorfoza sprowokowana przez dzieci czyni je niskimi, wesołkowatymi i głupimi (Warner 2000: 18). Dziecięcy śmiech ze strachu jest zatem ambiwalentny: wesoły, rubaszny, ale i szyderczy. W ,ambiwalentnym śmiechu wyraża się punkt widzenia całości stającego się świata, którego częścią jest również ten, kto się śmieje" (Bachtin 1975: 69). Monika Sznajderman rozwija Bachtinowską refleksję o śmiechu ambiwalentnym i pisze, że w karnawale mieszczą się różne rodzaje śmiechu, czasami jest to śmiech drwiący, ironiczny, bluźnierczy (Sznajderman 1994: 57). Dzieciom bliski jest „sardoniczny śmiech, wisielczy humor, diabelski rechot” kwestionujący wartości (tamże, 58). Groza w takim ujęciu zyskuje naturę jarmarczną, posiada odrębne obrazowanie, co Bachtin komentuje następująco: „Bez uwzględnienia tego momentu pokonanego strachu - w ogóle nie można zrozumieć obrazu groteskowego. To, co straszne, bierze oto udział w zabawie, jest wyśmiewane - staje się wesołym straszydłem" (Bachtin 1975: 167).

Nieoficjalny punkt widzenia rzeczywistości, w który wpisany jest rubaszny śmiech, przypisywanie straszydłom zachowań dziecinnych, oprawa fizjologiczna, poetyka absurdu i groteski oraz potocyzmy i wulgaryzmy, pojawiają się nie tylko w zaprezentowanych wierszach dziecięcych, ale także w wymyślanych przez nie strasznych historyjkach - repertuarze typowym dla dzieci w młodszym wieku szkolnym. Starsze dzieci, które postrzegają rymowanki jako infantylne, wymyślają krótkie opowiastki, do konstruowania których wykorzystują oprawę ludycznogroteskową zapożyczoną z rymowanek. Poetyka ta jest sprawdzona przez dzieci, które w tym wieku nadal potrzebują grozę kontrolować. Funkcją strasznych opowiastek podobnie jak rymowanek jest parodiowanie strachów. Dzieci kpią ze straszydeł, szczególnie duchów, upiorów, zombie i wampirów, ukazując ich braki, słabe strony, przypisując im głupotę i niezdarność, odzierając je z klasycznych atrybutów. W opowiastkach tych wyróżniają się szczególnie: profanacje, hiperbole, cięte riposty i ludyczne puenty wyzwalające w słuchaczach żywiołowy, spontaniczny śmiech. Straszne opowieści z zaskakującymi finałami inspirowane są topiką grozy znaną starszym dzieciom $\mathrm{z}$ folkloru ludowego, miejskiego, pedagogiki straszenia, ale także $\mathrm{z}$ kierowanego do dorosłych horroru literackiego i filmowego. Uludycznienie tej topiki $\mathrm{w}$ repertuarze dziecięcym pozwala dzieciom mediować między fascynacją grozą a potrzebą jej finałowego ośmieszenia. Jest to ważne szczególnie wówczas, gdy słuchaczami są młodsze i wrażliwe dzieci. One zdecydowanie muszą nacieszyć się 
puentą, poczuć, że to tylko zabawa w straszenie, że strachy są „,na niby” (Goldstein i in. 2007: 136). Warto dodać, że oprócz recytowania rymowanek i opowiadania strasznych opowiastek dzieci często stosują dodatkowy sposób na neutralizowanie strachu, jakim są spontaniczne rysunki, na których przedstawiają straszydła. W przekładzie interesemiotycznym istotne jest nadawanie cielesności monstrom, duchom i potworom, celowe karykaturyzowanie ich, wymyślanie słów, jakie mogą wypowiadać - innymi słowy, podporządkowanie ich regułom własnej wyobraźni.

Przykład opowiastki grozy zaczerpnęłam z angielskiego folkloru dziecięcego, w którym topika grozy jest bardzo popularna, szczególnie motyw żywego trupa lub ducha jest silnie eksploatowany przez dzieci. Przytoczona niżej historyjka opowiedziana została przez sześciolatka, którego poproszono o zaprezentowanie narracji o strachach:

This boy's mom told him to go to the store and get him some, get her some liver. But by the time he got to the store the store was closed. So there was a graveyard beside the store and so he went over there and dug up a person and got the liver out of him and took it home and they ate it that night. And that night he heard something. He heard a voice: "Johnny, I'm on the first step. Johnny, I'm at the second step. Johnny, I'm at the third step. Johnny, I'm in the hall. Johnny, I'm by your door. Johnny, I'm opening your door. Johnny, I'm in your room. Johnny, I'm by your dresser. Johnny, I'm by your posters. Johnny, I'm by your bed. Johnny, I GOTCHA!" (tamże, 198-199).

Ten rodzaj strasznej opowiastki zawiera wiele tematów tabu, które interesują dzieci: okradanie grobów, kanibalizm, okłamywanie rodzica, pojawienie się upiora (tamże, 119). Wyolbrzymiona puenta jest charakterystyczna dla tego typu opowiastek ${ }^{9}$. Opowiadający musi przerazić słuchaczy, dlatego finałowy okrzyk: „I GOTCHA!” jest punktem kulminacyjnym takiej narracji. Podczas opowiadania strasznych opowiastek $\mathrm{w}$ grupie dziecięcej opowiadacze ryczą $\mathrm{w}$ ekstazie w momencie wygłaszania puenty, grupa zaś krzyczy w podekscytowaniu $\mathrm{z}$ przerażenia. Mimo iż dzieci znają daną opowieść bardzo dobrze, zawsze odczuwają przyjemność z ponownego słuchania i przeżywania jej (tamże, 127). Szczególnie kiedy zmieniają się narratorzy, co pozwala dzieciom modulować głos, wcielać się w różne role, ćwiczyć gesty, stopniować napięcie, budować finał. Dla dzieci największe znaczenie ma finał właśnie, który Sylvia Ann Grider określa jako ,an essential structural feature of children's scary stories” (Grider i in. 2007: 121). Finałowy żart rozładowuje napięcie, szczególnie gdy opowiadaniu towarzyszy zabawa w straszenie się. W takiej sytuacji ludyczna puenta pomaga dzieciom zachować dystans do nastroju grozy i figur strachu, zaś krzyki i wrzaski zastępują chichoty, znaczące poszturchiwania, ataki śmiechu. Przykładowo duch, który straszył wszystkich słowami: „I'm the Ghost of the White Eye” musiał skonfrontować się $\mathrm{z}$ najmłodszym dzieckiem w rodzinie, które zeszło do piwnicy i wyegzorcyzmowało zjawę następującym zdaniem: „You better shut up or you're going to be the Ghost of the Black Eye!" (tamże, 212-213). Podobnie w opowiastce o nawiedzonym hotelu duch miał zwyczaj straszyć gości hasłem: „Bloody Fingers!”, do czasu kiedy jeden z nich zlekceważył go i odpowiedział: „Bandaids in the bathroom” (tamże, 217-218).

Wytworzenie ludyczno-groteskowego finału udaje się przede wszystkim bardzo zaangażowanym dziecięcym narratorom, którzy pragną mistrzowsko opowiedzieć historyjkę, by pozostałe dzieci słuchały jej z napięciem (tamże, 121). Warto podkreślić, że jest to repertuar ponownie nieprzeznaczony dla dorosłych, przekazywany w grupie 
rówieśniczej przed pójściem spać, podczas zabaw w straszenie się na koloniach czy podczas obchodzenia Halloween ${ }^{10}$. Teksty te są łatwo zapamiętywane przez młodsze dzieci. Już pierwsza fraza pozwala im poczuć się komfortowo $\mathrm{w}$ takim repertuarze, w którym strach jest bezpieczny, bo wyśmiany. Najmłodsi lubią też powtarzalność tego repertuaru, niezbyt częste wprowadzanie zmian, raczej cieszenie się tą samą opowiastką niż reinterpretowanie jej lub tworzenie nowych. Warto zauważyć, że ten sam stosunek mają młodsze dzieci do baśni czytanych im regularnie. Lubią, aby czytano im ciągle tę samą opowieść, zawsze $\mathrm{w}$ taki sam sposób - bez improwizacji, zmian i opuszczania ulubionych fraz lub fragmentów (szczególnie dotyczących grozy i makabry). Zwłaszcza dzieci, które boją się ciemności, straszydeł i potworów, słuchając regularnie podszytych ludycznością opowiastek strachu, uczą się dystansu do grozy poprzez „uwięzienie” straszydła w strukturze opowieści, dostrzeżenie jego figuratywności i machinalnej powtarzalności wykonywanych przez niego czynności np. powolnego wspinania się po schodach do pokoju dziecinnego. Opowiastka daje dzieciom szansę postrzegać repertuar straszenia jako materiał przewidywalny, skonwencjonalizowany, któremu nawet najmłodszy łatwo może nadać po Bachtinowsku rozumianą ,gębę”.

\section{Podsumowanie}

Świat grozy w oczach dziecka często bywa straszny - konstatacja ta dotyczy szczególnie dzieci w starszym wieku przedszkolnym i młodszym wieku szkolnym, których wyobraźnia rodzi mroczne obrazy i monstrualne straszydła, zaś magiczny i animistyczny sposób myślenia o zjawiskach niesamowitych i nadnaturalnych oraz swobodne fantazjowanie o nich sprawiają, że stają się one nazbyt realne w życiu dziecka a tym samym bardzo groźne. Mroczna wyobraźniowość może być zatem wrogiem dziecka, które na szczęście potrafi znaleźć samodzielnie sposób na jej katalizowanie. Dla dzieci katalizatorem strachu są wymyślane przez nie mikroformy wierszowane oraz krótkie opowiastki strach przedrzeźniające, towarzyszące zabawom $\mathrm{w}$ grupie rówieśniczej. Wiersze i opowiastki tego rodzaju powstają w przestrzeni zabawy, podczas której dzieci straszą się wzajemne i regulują ów strach katartycznym śmiechem. Rytuał obśmiewania grozy przez dzieci dowodzi, że repertuar strachu jest im znany podobnie jak magiczno-wierzeniowe, archetypiczne obrazy grozy, których proporcje dziecko zmienia, nadając im w miniaturowych formach oblicza à rebours.

Ośmieszone straszydła, jak przekonuje Bachtin, są dominantą kompozycyjną karnawału, który odwraca zwyczajowe normy, odrzuca oficjalną hierarchię w przypadku dzieci narzuconą przez dorosłych - i wprowadza repertuar ludycznogroteskowy. Poetyka karnawału, tak bliska dzieciom, sankcjonuje chaos, brak umiaru i reguły ,świata na opak” (Sznajderman 1994: 41). Karnawał dziecięcy jest sferą

${ }^{10} \mathrm{~W}$ opracowaniu Halloween and Other Festivals of Death and Life autorzy opisuja inicjację małych dzieci w Halloweenowy karnawał, podczas którego w groteskowych maskach i strojach wędrują one od domu do domu, licząc na możliwość recytowania frenetycznych rymowanek i robienia żartów i psikusów. Dziecięce żarty postrzegane są jako karnawałowe akty buntu (rituals of rebellion) służące oswajaniu śmierci oraz życia pozagrobowego. Dzieci najbardziej lubią kostiumy duchów, szkieletów, zombie, mumii, korpusów ciał, wampirów, wilkołaków, wiedźm, monstrów nawiązujących do tradycji strachu, ale też filmowych psychopatów. Oprawa karnawałowa pozwala najmłodszym wyzwolić się od norm egzekwowanych od nich na co dzień przez dorosłych i dać jawnie upust fascynacji straszydłami oraz ich życiem nocnym $\mathrm{z}$ jednoznacznym nastawieniem na ośmieszanie ich, czyli odreagowywanie strachu (Russell 1994: 109, 119). 
gestów przesadzonych, rymowanek turpistycznych, skatologicznych, makabrycznych, kompromitujących monolityczność estetyki grozy. Deformacja, wyolbrzymienie, deprecjacja tabu i szykana powagi stają się wyznacznikami wierszy i strasznych opowiastek kreowanych przez dzieci. Wyznaczniki te sprawiają, że groza w folklorze dziecięcym zdecydowanie różni się od grozy przeznaczonej dla dorosłego odbiorcy. Duchy, upiory, dzieciożercy, straszydła, mroczna nastrojowość traktowane sa w językowych zabawach najmłodszych prześmiewczo, utwory te cechuje zawsze ludyczna puenta. Mamy tu do czynienia $\mathrm{z}$ grozą skarnawalizowaną, repertuarem istniejącym $\mathrm{w}$ ustnym obiegu dzieci, nieprzeznaczonym dla dorosłych, nazywanym „podziemiem dziecięcym” (children's underground) (Goldstein i in. 2007: 111).

Jeżeli groza ma charakter nieprzenikniony i destrukcyjny zostaje przez dzieci natychmiast egzorcyzmowana śmiechem. Ów pierwiastek śmieszności nadaje jej status silnie groteskowy, co jest naturalne w kulturze dziecięcej. Przeistaczanie grozy w groteskę jest bowiem celem karnawału, o czym następująco pisze Tomasz Gryglewicz:

[...] istota obrazu groteskowego, jego rdzeń, uporczywie pozostaje niezmienna niezależnie od przestrzeni i czasu powstawania poszczególnego dzieła. Utwierdza nas w tym przekonaniu obecny we wszystkich kulturach $[\ldots]$ ten sam wizualny schemat monstrum o cechach zarazem demonicznych i śmiesznych (Gryglewicz 1984: 125).

Zabawy dziecięce są przejawem rytualnego wyszydzania grozy, mają funkcję przemiany jej znaczeń, gdyż odbijają ją w krzywym zwierciadle (Sznajderman 1994: 69). Dzieci dają upust rubaszności, sprośności, śmiechowi sardonicznemu i w ostentacyjny sposób „tykają" symbolicznych reprezentantów strachu, pastwią się nad nimi, nawet ich uśmiercają. Topika grozy jako repertuar peryferyjny zostaje w karnawale dziecięcym wzniesiona na piedestał - co Gryglewicz przedstawia jako przejście marginesu do sfery centralnej - następnie $\mathrm{z}$ tego piedestału zrzucona, trywialnie zdegradowana, brutalnie pozbawiona pierwotnej, złowieszczej wartości i mocy (Gryglewicz 1984: 23). Dzieci w zabawie cechuje profaniczna postawa wobec strachu. Rymowanki odmieniają sens i znaczenie tego, co niesamowite, lękowe i demoniczne. Najmłodsi dostrzegają dziwaczno-komiczne oblicze grozy, kwestionują jej powagę i majestat, znajdując w niej to, co niskie i cielesne.

Warto na koniec zauważyć, choć nie ma tu miejsca na szczegółowe omawianie tego tematu, że karnawalizacja grozy, wywiedziona z poetyki rymowanek dziecięcych, staje się dominantą kompozycyjną wielu książek obrazkowych dla dzieci szczególnie zagranicznych (Slany 2016b: 23-36). Twórcy literatury dla dzieci odnajdują w rymowankach preferowany przez nie ludyczny i groteskowy sposób traktowania grozy i prezentują karnawałowo topikę strachu. Wiele współczesnych książek obrazkowych bawi się repertuarem Halloweenowych psikusów, prezentuje monstruarium ludyczne i grozotwórcze portrety dzieci oraz łagodzi lęki przed ciemnością, straszydłami wywiedzionymi z baśni, pedagogiki ludowej oraz literackofilmowego horroru (Kostecka 2016). Warner pisze, że uniwersalną metodą poskramiania koszmarów w książce dziecięcej stało się nadawanie im groteskowego wyrazu, a następnie deklarowanie ich fikcjonalności i pozwolenie dziecku na samodzielną konstatację, że straszydła są żenująco infantylne, potwornie śmieszne oraz „uwięzione w książee” (Warner 2000: 325). Badaczka twierdzi, że używanie ludycznych hiperbol i groteskowych ekscesów pozwala dzieciom zdystansować się do strachów, pośmiać jowialnie z ich karykaturalnych wizerunków i uznać je za twory zmyślone, pozbawione realnych odpowiedników, istniejące jedynie w sferze wyobraźni (tamże). Dodaje, że autorów cieszy traktowanie dziecka jako partnera zabawy, bycie 
z nim w relacji koleżeńskiej, oraz fakt, że potrafią sprostać jego emocjonalnym oczekiwaniom:

Opowieści z elementami makabry i grozy wywołują różnego rodzaju reakcje - od przestrachu do śmiechu, od przerażenia do uczucia przyjemności, gdyż przez moment [dla dzieci - K.S.] nie ma w nich nic lepszego od pożerającego wszy olbrzyma, który idzie po swą zdobycz, czym doprowadza dziecko do euforii i chichotu [...] (tamże, 7) ${ }^{11}$.

Karnawałowe podejście do grozy, preferowane przez dzieci młodsze, wystarczająco długo należało do podziemia kultury dziecięcej. Współcześnie stało się elementem kultury oficjalnej, a drażliwy repertuar strachu został świadomie połączony z dzieckiem przez pisarzy, literaturoznawców, psychologów i pedagogów, których coraz mniej przeraża wizja dziecka zafascynowanego grozą, bawiącego się i cieszącego się nią.

\section{Bibliografia}

BACHTIN, M. (1975). Twórczość Franciszka Rabelais'go a kultura ludowa średniowiecza $i$ renesansu (przeł. A., A., Goreniowie). Kraków: Wydawnictwo Literackie.

BETTELHEIM, B. (2010). Cudowne i pożyteczne. O znaczeniach $i$ wartościach baśni (przeł. D. Danek). Warszawa: W.A.B.

CIEŚLIKOWSKI, J. (1985). Wielka zabawa. Folklor dziecięcy, wyobraźnia dziecka, wiersze dla dzieci. Wrocław: Zakład Narodowy im. Ossolińskich.

EVERS, L. (2014). Here Comes a Chopper to Chop Off Your Head. The Dark Side of Childhood, Rhymes and Stories. London: Metro.

GOLDSTEIN, D., Grider, S. A., Thomas, B. J. (2007). Haunting Experiences. Ghosts in Contemporary Folklore. Logan-Utah: Utah State University Press.

GRYGLEWICZ, T. (1984). Groteska w sztuce polskiej XX wieku. Kraków: Wydawnictwo Literackie.

JANUS-SITARZ, A. (1997). Groteska literacka. Od diabła w Damaszku po Becketta i Mrożka. Kraków: Universitas.

JONCA, M. (2005). Enfants terribles. Dzieci złe, źle wychowane w literaturze polskiej XIX wieku. Wrocław: Wydawnictwo Uniwersytetu Wrocławskiego.

KĘPIŃSKI, A. (1979). Lęk. Warszawa: Państwowy Zakład Wydawnictw Lekarskich. KOSTECKA, W. (2016). Śmiech błazeński $w$ literaturze $i$ kulturze popularnej dla dzieci. W: G. Leszczyński (red.), Do śmiechu. Komizm w sztuce dziecka (s. 200-215). Poznań: Centrum Sztuki Dziecka.

NIKOLAJEVA, M. (2000). From Mythic to Linear. Time in Children's Literature. Lanham: Scarecrow Press.

Nowe fikotki Pana Pierdziołki. Powtarzanki i Śpiewanki (2013). Poznań: Zysk i S-ka.

${ }^{11}$ Przekład własny za: „Gruesome and violent tales range in their effect from awe to laughter, from terror to pleseure, but for the moment there is nothing like a lesh-eating giant coming for his prey to make a child thrill and giggle $[\ldots]$ ". 
OLKUSZ, K. (2010). Współczesność w zwierciadle horroru. O najnowszej polskiej fantastyce grozy. Racibórz: Wydawnictwo Państwowej Wyższej Szkoły Zawodowej w Raciborzu.

Patka, zapałka, dwa kije. Niegrzeczne rymowanki (2014). Toruń: Literat.

PAPUZIŃSKA, J. (1996). Dziecko w świecie emocji literackich. Warszawa: Stowarzyszenie Bibliotekarzy Polskich.

PISARKOWA, K. (2013). Wyliczanki polskie. Ene, due, rabe. Kraków: Petrus.

RUDOLF, E. (2001). Świat istot fantastycznych we wspótczesnej literaturze popularnej. Wałbrzych: Wydawnictwo Państwowej Wyższej Szkoły Zawodowej w Wałbrzychu.

RUSSEL, W. B. (1994). Carnival, Control, and Corporate Culture in Contemporary Halloween Celebrations. W: J. Santino (red.), Halloween and Other Festivals of Death and Life (s. 109-119). Knoxville: University of Tennessee Press.

SIMONIDES, D. (1986). Ele, mele, dudki. Rymowanki dzieci śląskich. Katowice: Śląski Instytut Naukowy.

SLANY, K. (2016). Monstruarium ludyczne w anglojęzycznych ksiażkach obrazkowych dla dzieci. „Guliwer”, nr 2, 23-36.

SLANY, K. (2016). Groza w literaturze dziecięcej. Od Grimmów do Gaimana. Kraków: Wydawnictwo Naukowe Uniwersytetu Pedagogicznego.

SZNAJDERMAN, M. (1994). Zaraza. Mitologia dżumy, cholery i Aids. Warszawa: Semper.

USENKO, N., Wawiłow, D. (2011). Stare i nowe wyliczanki. Tere-fere kuku. Poznań: Papilon.

WARNER, M. (2000). No Go the Bogeyman. Scaring, Lulling and Making Mock. London: Vintage.

WĄDOLNY-TATAR, K. (2014). Kolysanka w liryce XX i XXI wieku. Emergencja gatunku literackiego. Kraków: Wydawnictwo Naukowe Uniwersytetu Pedagogicznego. WORTMAN, S. (1958). Baśń w literaturze $i$ życiu dziecka. Co i jak opowiadać? Warszawa: Stowarzyszenia Bibliotekarzy Polskich.

ZYCH, P., VARGAS, W. (2015). Bestiariusz słowiański. Rzecz o skrzatach, wodnikach i rusatkach. Olszanica: BOSZ.

\section{Strony internetowe}

http://forum.gazeta.pl/forum/f,384,Forum_Humorum.html [dostęp: styczeń 2017]. 


\section{KATARZYNA SLANY}

\section{CARNIVALIZATION OF FEAR IN CHILDREN'S FOLKLORE}

The article tackles the topic of creative language developed by children in the kindergarten- and early-primary-school-age. This language is marked by composition dominants of absurdity, grotesque, macabre, impropriety, obscenity, scatological humor, childishness, profanity, hyperboles, and ludic punch lines. The main subject of the analysis is children's folklore, which is a spontaneous verbal rhymed activity and expression accompanying children's play. This type of improvised poetic micro-forms is common for children's culture and is engendered in peer-group environments. They thus occur outside of the official language culture and serve as a verbal form of rebellion, effectuated by children against the imposition of the adults' language. The latter is conversely characterized by properness, formality, instrumental nature, and its aim to mirror reality. Children gain satisfaction from breaking language taboos and introducing consternation among their elders. In their verbal productions, one can observe a typically carnivalized gesture, which is the elevation of the weakest subject of the social hierarchy. In this sense, a child can instill a different and carnivalized version of the world through play. The analysis encompasses the rhymed and narrative short forms present in the verbal realm of children's lives and depicting a carnivalized fear. Adopting a carnival lens for looking at children's use of being afraid is a symptom of rejecting the monolithic nature of fear. Children appear to perform an exorcism on fear through laughter, try to neutralize it and ascribe the fears with that Bakhtin could see as building a ludic and grotesque version of a world upside-down. 